\title{
A NEW SPECIES OF CATASETUM (ORCHIDACEAE, EPIDENDROIDEAE, CYMBIDIEAE) FROM THE SOUTHERN BRAZILIAN AMAZON
}

\author{
Mathias Erich Engels ${ }^{1,4}$, Lilien Cristhiane Ferneda Rocha ${ }^{2} \&$ \\ Adarilda Petini-Benelli ${ }^{3}$ \\ ${ }^{1}$ Assessoria Técnica Ambiental Ltda., Marechal José Bernardino Bormann Street, 821, Batel, \\ Curitiba, Paraná, Brazil, 80730-350 \\ ${ }^{2}$ Juris Ambientis Consultores S S Ltda., Humberto Carta Street, 96, Hugo Lange, Curitiba, \\ Paraná, Brazil, 80040-150 \\ ${ }^{3}$ Federal University of Mato Grosso, Fernando Correa da Costa Avenue, Boa Esperança, Cuiabá, \\ Mato Grosso, Brazil, 78060-900 \\ ${ }^{4}$ Correspondence author: mathiasengels@hotmail.com
}

\begin{abstract}
Catasetum colidense, from margins of the Teles Pires River, Mato Grosso State, Brazil, is described and illustrated. The new species is compared with morphologically similar species.

Resumo. É descrita e ilustrada Catasetum colidense, oriunda das margens do rio Teles Pires, estado de Mato Grosso, Brasil. A nova espécie é comparada com as espécies morfologicamente próximas.

Key words: Amazon, Catasetum, epiphyte, Mato Grosso State, Neotropics, Teles Pires River.

Palavras chave: Amazônia, Catasetum, epífita, Mato Grosso, Neotrópico, rio Teles Pires.
\end{abstract}

Introduction. The genus Catasetum Rich. ex Kunth has a controversial number of species, 130 according to Romero (2009), versus circa 200 species according to Govaerts (2016). They are found from Mexico to Paraguay and Argentina (Govaerts 2016). In Brazil circa 105 species are known to occur, they are distributed all around the country, however, a higher richness is found in the Amazonian biome. The Mato Grosso State is highly representative, with 34 species and two natural hybrids (Petini-Benelli \& Grade 2008, 2010, Koch \& Silva 2012, Petini-Benelli 2012, BFG 2015, Petini-Benelli et al. 2015, Petini-Benelli \& Soares-Lopes 2015).

The North region of Mato Grosso is on the Austral limit of Amazonia and has a rich flora, that is scarcely known (Zappi et al. 2011, 2016). Recently it has produced many novelties, including new records of geographic distribution (eg. Vilela-Santos et al. 2013, Petini-Benelli et al. 2015, Engels \& Ferneda Rocha 2016a,b) and new species (eg. Petini-Benelli \& Grade 2008, 2010, Vanderplank \& Zappi 2011, Petini-Benelli $\&$ Soares-Lopes 2015).
The new species of Catasetum that is here described and illustrated was found during the flora rescue of the hydroeletric power plant of Colider, in the Teles Pires River, North-Central Mato Grosso State.

\section{RESULTS}

Catasetum colidense M.E.Engels, L.C. Ferneda Rocha \& A. Petini-Benelli sp nov. Type: BRAZIL. Mato Grosso: Colíder, Flora Rescue from UHE Colíder, ( $\overbrace{}^{\lambda}$ ), 22 January 2015, M.E. Engels 4640 (Holotype MBM!; Isotypes HERBAM!, RB!, TANG! [spirit collection]). FIG. 1-2.

Catasetum albovirens Barb.Rodr. et C. matogrossense Bicalho similis sed resupinata stamineae floribus, subquadrate labelum medium lobus et labelum ostium apertum magis differt. Catasetum cotylicheilum D.E.Benn. \& Christenson similis sed labellum basis absque callum, carinatum labellum centrum, subqudrate labelum medium lobus et antennae intra labelum ostium differt. 


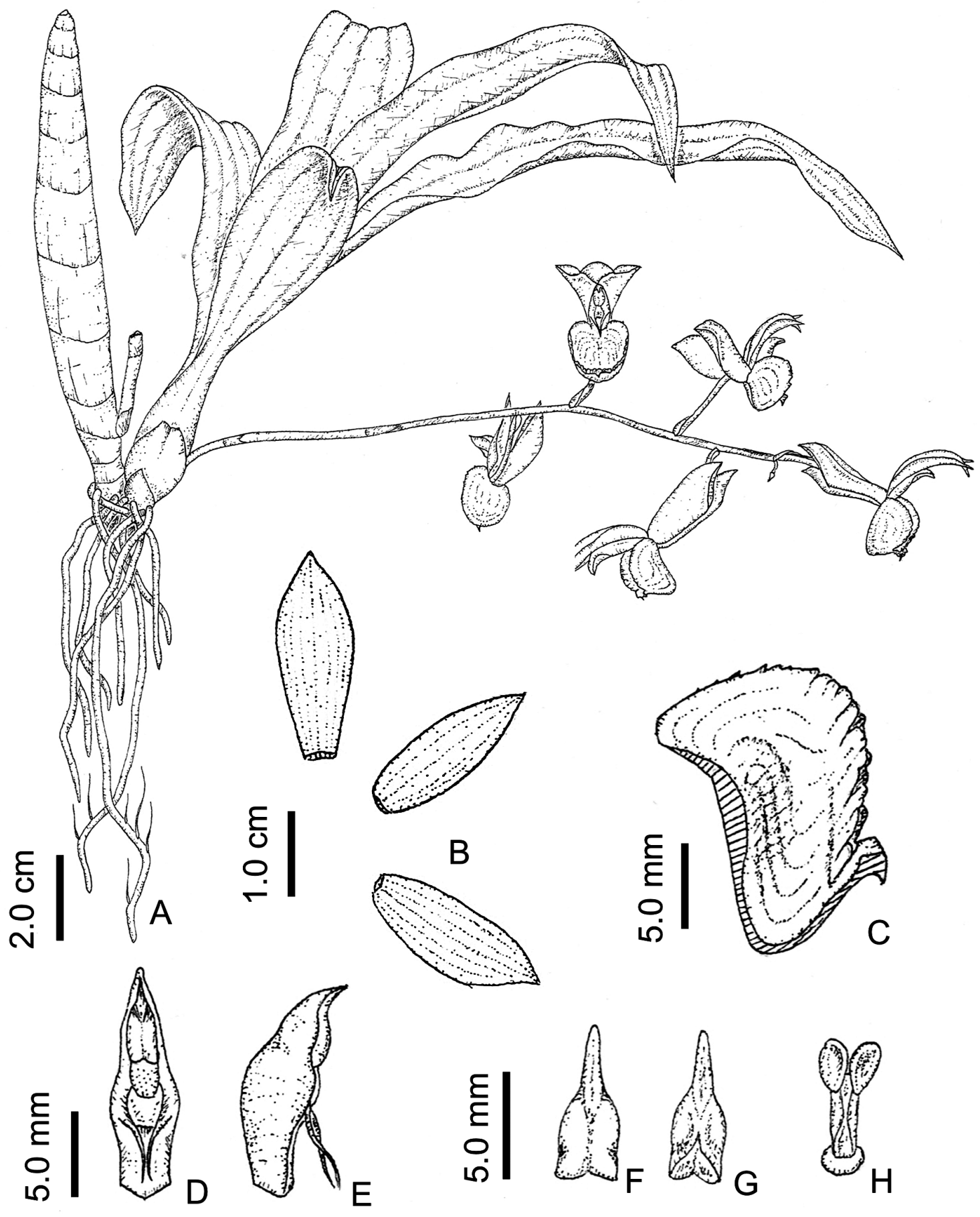

Figure 1. Catasetum colidense. A. Habit. B. Flattened perianth. C. Sectioned lip in lateral view. D. Column in frontal view. E. Column in lateral view. F. Anther in dorsal view. G. Anther in ventral view. H. Pollinarium (M.E.Engels 4639). Illustration by M.E.Engels. 


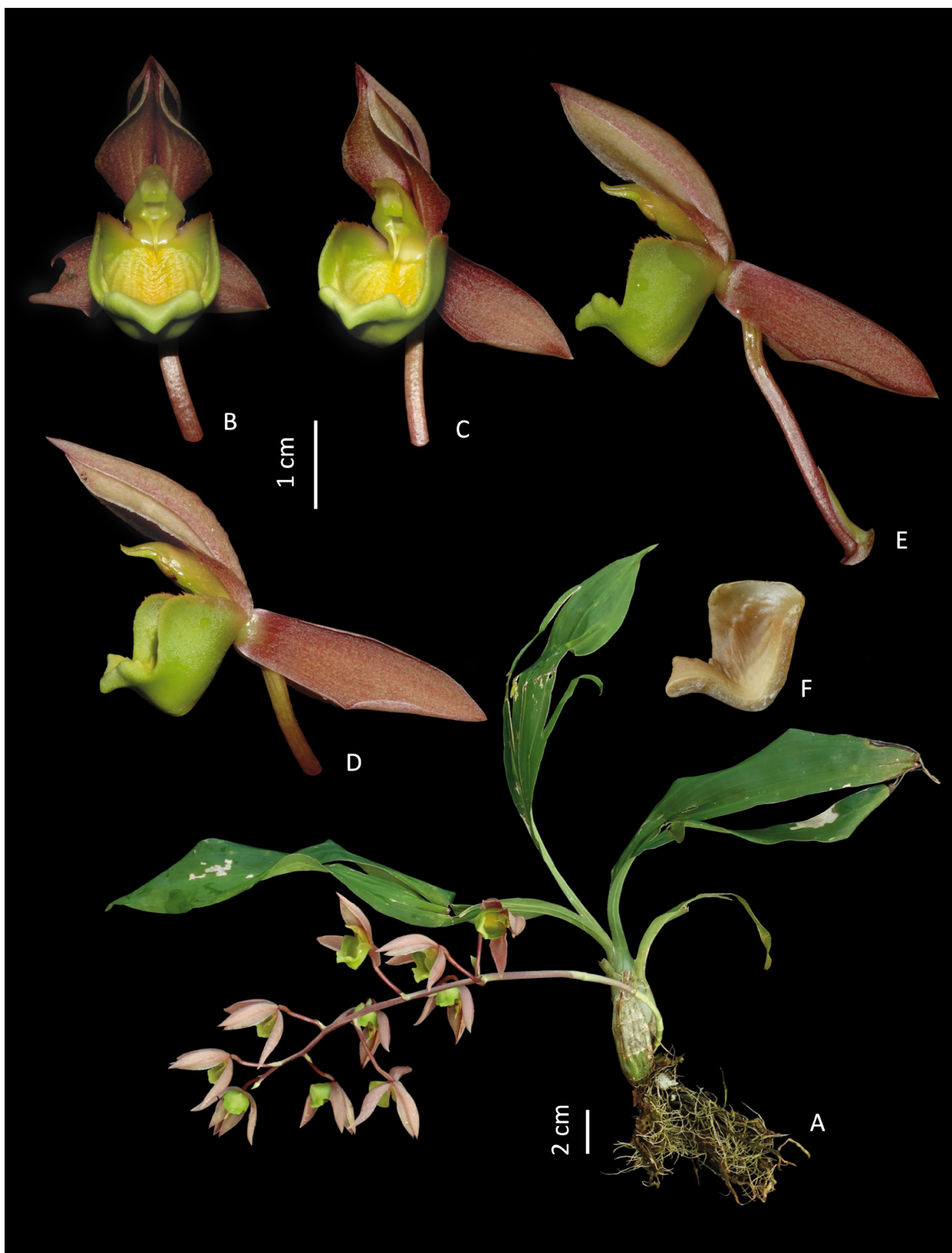

Figure 2. Catasetum colidense. A. Habit. B. Flower in frontal view. C-D. Flower in diagonal view. E. Flower in lateral view. F. Lateral view of lip in sagittal section (A. M.E.Engels 4638, B-F. M.E.Engels 4640). Photos by M.E.Engels. 
Epiphytic herbs, caespitose. Roots 1-3 mm thick, terete, whitish. Rhizomes ca. $5 \mathrm{~mm}$ thick, $0.5-1.0 \mathrm{~cm}$ between pseudobulbs, terete. Pseudobulbs 4.8-16.3 $\times 1.0-4.7 \mathrm{~cm}$, heteroblastic, fusiform, green when foliated to brownish when mature. Leaves 16.6-50.5 $\times 3.4-7.0 \mathrm{~cm}$, elliptic, flat, nerves sunken adaxially and prominent abaxially, green, slightly discolor. Inflorescence basal, curved, 5-34 flowers; peduncle 8-24 $\times 0.2-0.5 \mathrm{~cm}$, terete, brown-pinkish; peduncle bracts $1.0-1.8 \times 0.6-1.4 \mathrm{~cm}$, amplective, obovate, obtuse, pale green; rachis $5.9-42.3 \times 0.1-0.3 \mathrm{~cm}$, terete, brown-pinkish; floral bracts $0.3-1.5 \times 0.3-0.4$ $\mathrm{cm}$, deltoid to triangular, acute, pale green. Staminate flowers, resupinate; ovary and pedicel 2.2-4.8 $\times 0.1$ $0.2 \mathrm{~cm}$, terete, brown-pinkish to brown-reddish; dorsal sepal 2.5-3.2 × 0.4-0.6 cm, elliptic-oblanceolate, base cuneate, margin entire, apex acute, brown-pinkish to brown-reddish; lateral sepals $2.3-3.2 \times 0.8-0.9 \mathrm{~cm}$, elliptic-lanceolate, base cuneate, margin entire, apex acute, brown-pinkish to brown-reddish; petals 2.5-3.2 $\times 0.6-0.7 \mathrm{~cm}$, oblanceolate, base acute, margin entire, apex acute, brown-pinkish to brown-reddish; lip 1.5$1.7 \times 2.0-2.2 \mathrm{~cm}$, stiff, fleshy, globose, $1.0-1.3 \mathrm{~cm}$ length, trilobate, pale green, adaxial surface yellow in center; lateral lobes $1.1-1.2 \times 0.5-0.6 \mathrm{~cm}$, rounded, margin serrate in proximal third, dentate at ca. $2 / 3$ distal; central lobe $0.2-0.4 \times 0.6-0.8 \mathrm{~cm}$, sub quadrate, margin dentate-callous, apex obtuse to sub truncate; central portion of lip with longitudinally keels and stretch transversal slightly verrucose, the longitudinal keel may extend into the margins of the central portion of the lip, it is slightly dentate-callous and very similar to margin of the central lobe, this keel can be more or less developed. Column $1.5 \times 0.3-0.5 \mathrm{~cm}$, pale green; antennae 2, ca. $5 \mathrm{~mm}$ length, equal, filiform, whitish, enclosed by the lip cavity in a side view; anther ca. 6-7 $\times 3 \mathrm{~mm}$, elliptic, apiculate, pale green-yellowish; viscidium ca. $1.5 \times 1.5 \mathrm{~mm}$, rounded, pale brown; stipe ca. $3 \times 1.0-1.5 \mathrm{~mm}$, oblanceolate, white-brownish; pollinia 2, ca. $2 \times 1 \mathrm{~mm}$, obovate, flattened, yellow. Pistillate flowers not seen. Fruits and seeds not seen.

Additional examined material (Paratypes). BRAZIL. Mato Grosso: Colíder, Flora Rescue from UHE Colíder, (ふ), 12.XII.2014, M.E. Engels 4637 (MBM!); Idem (ð), 31.I.2015, M.E. Engels 4638 (MBM!); Idem (ð), 11.I.2016, M.E. Engels 4639 (TANG! spirit collection).
Eтymology. The specific epithet refers to the type locality, county of Colíder, Mato Grosso State, Brazil.

Catasetum colidense is morphologically similar to the Brazilian species $C$. albovirens and $C$. matogrossense. However, it differs from those by the staminate flowers resupinate ( $v s$. non-resupinate) and the central lobe of lip sub quadrate ( $v s$. rounded to sub deltoid). Besides that, the ostium of the lip is more open in C. colidense than in the compared species. Another species very close is Catasetum cotylicheilum D.E.Benn. \& Christenson, endemic of Peru, but there are several differences between them, including the staminate flowers without callous in the lip base ( $v s$. lip base with callous), the central lobe sub quadrate and slightly thickened ( $v s$. central lobe deltoid and strongly thickened), the central portion of the lip with longitudinally keels and stretch transversal slightly verrucose ( $v s$. keels and stretch absent), and the column antennae enclosed by the lip cavity in a side view (vs. totally outside of the lip cavity). Catasetum colidense belong to subgenus Catasetum, section Isoceras, subsection Convergens, with antennae first converging near the base and then parallel at the apex, directed towards the center of the lip.

This species is found as an epiphyte in forests at the margins of the Teles Pires River, in Seasonal Evergreen Alluvial Forest. Flowers were observed from December to January. The flowering occurs when the pseudobulb is already developed and before the leaves fall (for types of flowering see Faria et al. 2016).

Acknowledgments. We thank Companhia Paranaense de Energia (COPEL) for allowing and encouraging the publication of this work, and the Consórcio CIA Ambiental and its staff.

\section{LiteRATURE CITED}

BFG (The Brazil Flora Group). (2015). Growing knowledged: an overview of Seed plants diversity in Brazil. Rodriguésia, 66(4), 1085-1113.

Engels, M.E. \& Ferneda Rocha, L.C. (2016a). Maxillaria aureoglobula (Orchidaceae, Maxillariinae): a new record from Brazil. Lankesteriana, 16(2), 119-122. doi: http://dx.doi.org/10.15517/lank.v16i2.25395. 
Engels, M.E. \& Ferneda Rocha, L.C. (2016b). Vanilla appendiculata (Orchidaceae): primeiro registro para o estado do Mato Grosso, Brasil. Rodriguésia, 67(3), 855-858.

Faria, R.T., Colombo, R.C., Oliveira, L.V.R. \& Camolesi, M.R. (2016). Orquídeas do gênero Catasetum no Brasil. Londrina, Mecenas, p. 160.

Govaerts, R. (2016). World Checklist of Selected Plant Families. Facilitated by the Royal Botanic Gardens, Kew. Available in: <www.kew.org/wcsp/monocots> Access: 17 July 2016.

Koch, A.K. \& Silva, C.A. (2012). Orquídeas nativas de Mato Grosso. Cuiabá, Carlini \& Caniato Editorial, p. 112.

Petini-Benelli, A. (2012). Orquídeas de Mato Grosso Genus Catasetum L.C. Rich ex Kunth. Rio de Janeiro, Pod, p. 130.

Petini-Benelli, A. \& Grade, A. (2008). A new species of Catasetum (Orchidaceae) for the State of Mato Grosso, Brazil. Edinburgh Journal of Botany, 65(1), 27-34. doi: https://doi.org/10.1017/S0960428608004824

Petini-Benelli, A. \& Grade, A. (2010). Novo Híbrido Natural de Catasetum L. C. Rich ex Kunth (Orchidaceae) para o Norte de Mato Grosso, Brasil. Orquidário, 24(4), 124-132.

Petini-Benelli, A. \& Soares-Lopes, C.R.A. (2015). A new species of Catasetum (Cymbidieae, Epidendroideae, Orchidaceae) from the Southern region of the Brazilian
Amazon. Phytotaxa, 204(1), 75-79. doi: http://dx.doi. org/10.11646/phytotaxa.204.1.6

Petini-Benelli, A., Soares-Lopes, C.R.A., Silva, D.R. \& Ribeiro, R.S. (2015). Novos registros de epífitas vasculares para o estado de Mato Grosso, Brasil. Enciclopédia Biosfera, 21(11), 2340-2351.

Romero, G.A. (2009). Distribution [of Catasetum]. In: Pridgeon, A.M., Cribb, P.J. \& Chase, M.W. (Eds.) Genera orchidacearum 5, Epidendroideae (part two) (pp. 1-14). Oxford: Oxford University Press.

Vanderplank, J. \& Zappi, D.C. (2011). Passiflora cristalina, a striking new species of Passiflora (Passifloraceae) from Mato Grosso, Brazil. Kew Bulletin, 66(1), 149153. doi: 10.1007/s12225-011-9255-2

Vilela-Santos, M.C., Barbosa, L., Santos, Q.C., Bao, F. \& Rodrigues, D. (2013). New records of Sciaphila Blume, Sciaphila purpurea Benth; Triuris Miers and Triuris hyalina Miers in the southern Amazon forest, Mato Grosso, Brazil. Check List, 9(4), 867-869.

Zappi, D.C., Milliken, W., Soares-Lopes, C.R.A., Lucas, E., Piva, J.H., Frisby, S., Biggs, N. \& Forzza R.C. (2016). Xingu State Park vascular plant survey: filling the gaps. Brazilian Journal of Botany, 39(2), 751-778. doi: 10.1007/s40415-016-0262-2

Zappi, D.C., Sasaki, D., Milliken, W., Iva, J., Henicka, G.S., Biggs, N. \& Frisby, S. (2011). Plantas vasculares da região do Parque Estadual Cristalino, norte de Mato Grosso, Brasil. Acta amazonica, 41(1), 29-38. 
LANKESTERIANA 